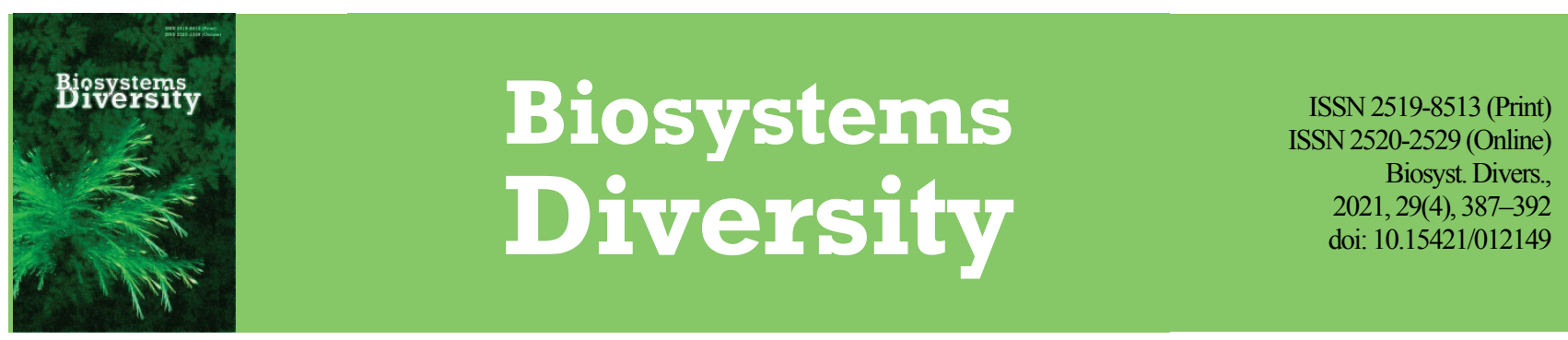

\title{
Summer coastal rookeries and perspectives of the Baikal seal (Pusa sibirica) population in the conditions of the global warming
}

\author{
E. A. Petrov, A. B. Kupchinsky, V. A. Fialkov \\ Baikal Museum of the Research Center, Listyyanka, Russia
}

Article info

Received 12.10.2021

Received in revised form

09.11 .2021

Accepted 11.11.2021

Baikal Museum

of the Research Center,

Akademicheskaya st., $1 A$

Listryanka, 664520,

Russia

Tel.: +7-395-245-31-46

E-mail:

evgen-p@yandex.ru

\section{Petrov, E. A., Kupchinsky, A. B., \& Fialkov, V. A. (2021). Summer coastal rookeries and perspectives of the Baikal seal (Pusa sibirica) population in the conditions of the global warming. Biosystems Diversity, 29(4), 387-392. doi:10.15421/012149}

Based on the secondary literature, a retrospective characterization of the climate in the Baikal region, starting from the end of the Pleistocene, is given. According to satellite monitoring data, the characteristics of the ice regime of the Lake Baikal in the conditions of climate warming are presented. Moreover, we briefly discuss the impact of climate change on the ecology and biology of the Baikal seal (Pusa sibirica $\mathrm{Gm}$.). Using video materials obtained online at one of the main island coastal rookeries of seals (on the island of Tonkyi, the archipelago of the Ushkany Islands, Lake Baikal) in 2011-2017, the dependence of the number of seals hauled out on the lake level and the peculiarities of the fishing regime was determined (the survey was conducted from May-June to October). A direct relationship was determined between the relative number of animals that had a moulting delay and the ice regime of a given year: the longer the floating ice in the northern part of Lake Baikal remained, the more numerous were the first approaches of seals to the studied rookery and the greater was the proportion of moulting individuals. It is reasonable to assume that the main reason for the Baikal seal to come ashore is not prolongued moulting time, but a physiological need for sunlight, which has a healing effect on the body of animals that lack solar radiation in winter. In general, climate warming has a negative impact on the state of the Baikal seal population. The available paleoclimatic reconstructions of the Holocene indicate that the population of the Baikal seal has experienced a lot of climate changes in its history. Nevertheless, if the current trends of climatic changes persist until the end of the 21 st century, the ecology and biology of the seal will drastically change (up to the beginning of terrestrial reproduction), and the population will significantly decrease. However, the Baikal seal as a species would remain.

Keywords: Baikal seal; coastal rookeries; shore rookeries; molting; climate warming; species conservation.

\section{Introduction}

Lake Baikal is inhabited by one seal species - the Baikal seal (Pusa sibirica $\mathrm{Gm}$.), and it is the only mammal in the ecosystem the population of which completes the lake's food chain. The status of the seal population indicates the well-being of the entire ecosystem or at least its pelagic part. Most of the seals' life (which is generally pelagic) is connected with ice due to its northern roots - the ancestors of the Baikal seal came to the freshwater Baikal, located in the center of Asia, most likely from the north in the Ice Age (Numachi et al., 1994; Sasakiet al., 2003).

The individual features of the Baikal seal are clearly shown at the birth of the pup (i.e. covered in white-yellowish fur, born in the winter and fed in a snow shelter) or during annual moults the annual molting period, which normally occurs on floating ice (Ivanov, 1982). In the 1960s and 1980s, the whole process of seal moulting, regardless of sex and age, took only 15-20 days. After June 15, moulting animals were rare. Moulting seals in October-November were considered unusual. The seals disperse along the lake when there is no floating ice. To feed, they explore the water column to $300-400 \mathrm{~m}$ depth. Those animals that were unable to moult on the floating ice cannot finish moulting (Petrov, 2009).

However, the seals still need to go ashore to form rookeries. Some shore rookeries are numerous, and there are many of them in the Baikal. It is unknown yet which part of the seal population visits the shore during the summer-autumn period and what makes the animals form coastal haul-outs that sometimes comprise hundreds of individuals (Ivanov, 1938; Pastukhov, 1993; Petrov, 1997; Petrov, 2009). But there must be important reasons to spend time on the shore.

Recently, the researchers observed that the importance of the shore in the life of seals has increased. It manifests in the formation of new haulouts and the increase of its seal populations (Petrov \& Kupchinsky, 2021; Petrov et al., 2021). The authors associate these changes with climate change in Lake Baikal, which occurs due to global climate dynamics.
In Baikal, warming occurs mainly due to rising temperatures in winter and spring, and very intensely and faster than in the Arctic on average (Kuimova et al., 2010; Shimaraev et al., 2014).

From the early 1970 s to the mid-1990s, a rising phase was observed, which showed an abnormally high increase in air temperature $\left(\mathrm{T}_{\mathrm{a}}\right)$ : by $3.5^{\circ} \mathrm{C}$ in the winter, and $1.3-1.9^{\circ} \mathrm{C}$ in the other seasons. In the some parts (basins) of the lake, stretched $600 \mathrm{~km}$ in the meridional direction, the climatic conditions differ substantially, but the rates of warming in the northern part is greater than in the southern part (Kuimova \& Shersteinkin, 2008). This dependence was also seen for the water - there was a positive trend in water temperature $\left(\mathrm{T}_{\mathrm{w}}\right)$ for the entire active layer (up to $300 \mathrm{~m}$ ) (Shimaraev et al., 2009), and an increase in the duration of "warm" periods. Changes in the ice conditions are significant. During the 20th century, the ice formation period in southern Baikal shifted by 11 days later on average than the norm. The maximum ice thickness $\left(\mathrm{H}_{\max }\right)$ decreased at the average rate of $0.24 \mathrm{~cm}$ per year (during the 1949-2000 period), the ice formation period decreased by 18 days, and the ice opening began seven days earlier (Shimaraev et al., 1991). According to other estimations from 1950 to 2007, the ice period shortened by 12 days, according to which the the maximum ice thickness $\left(\mathrm{H}_{\max }\right)$ decreased by $15-16 \mathrm{~cm}$, both in the south and north of the lake (Kuimova \& Shersteinkin, 2008).

Climatic changes in the ice conditions have negatively affected the ecology and behaviour of the Baikal seal. Using the example of changing process in the hair coat (one of the most important physiological processes determining the health and well-being of the seal population), the authors attempt to find out how the changing conditions of ice affect the life of the Baikal seal in the most unexplored, "land" period of their life.

\section{Materials and methods}

In the main coastal rookery that seals visit annually - on Tonkiy Island of the Ushkan Islands Archipelago- a camera was installed for "on- 
line" monitoring animal behaviour. The Ushkan Islands are situated at the border of the South and North Basins of Lake Baikal and are part of the "Joint Directorate of the Barguzinsky State Nature Biosphere Reserve and Zabaikalsky National Park LLC.

There follows a description of the basic scheme for the organization of remote observations and the basic technical parameters of the equipment (Fialkov et al., 2014). We used an Axis Q6035-E dome camera. Information transmission from the island and control of the video camera was carried out using RADWIN 2000C equipment, through a high-speed communication channel formed by transponders. The power was received from the solar panels and an Apollo-650 wind generator. The video was shot daily in automatic mode (regardless of weather conditions) from 6 to $8 \mathrm{am}$ to 9 to $11 \mathrm{pm}$. For several years, high-quality images from the site of the observations were available on the Internet in real-time. Now, this video material is archived (the M-JPEG resource-intensive compression standard) and stored in the Baikal Museum collections.

The main investigation method was visual observation and capturing behavioural acts and positions of the animals (ethogram). Screenshots captured the animal positions - when animals took positions of functional importance, the frames of the video materials were captured into the photograph (screenshot) and then described. The authors paid particular attention to the physical condition of the animals (sex, size, moulting, and nutritional status). In particular, the main signs of moulting were the coloration of animals (predominance of brown-yellow-rusty shades), condition of hair coat on the back and sides, no grown whiskers, and others. The research was based on video material shot during the summer-autumn seasons of 2011-2017. The "close-up" observations were carried out mainly on a small section of the rookery called Kamushek (Little Stone). This is a flat, moderately rocky cliff close to the shore, with a square area of $\approx 20-25 \mathrm{~m}^{2}$. This cliff receives special attention from the seals, but the water level determines its accessibility. Some data were calculated by standard methods of variational statistics, $\mathrm{x} \pm \mathrm{SE}$ (mean \pm standard error, $\mathrm{n}$ - the number of animals or days of observations).

\section{Results}

The dates of ice formation and destruction in the southern and northern parts of Baikal between 2011 and 2017 were significantly different (Table 1). The duration of the ice period in southern Baikal ranged from 63 to 111 days (difference of 1.8 times); in the northern part - from 99 to 132 days (1.3 times, Table 2). It is clear that the ice period was longer in northern Baikal. But the length of the period of floating ice (where the seal moulting occurs) in both parts of the lake varied by three times from year to year. Comparing these characteristics revealed no clear picture in southern and northern Baikal. In the southern part, the length of the ice period equaled, on average, $71 \%$; in the northern part the period of floating ice was $95 \%$. In some years, this period was longer in the south than in the north (Table 2). When the water level allows the animals to climb to the relatively high Kamushek, they usually use it to some extent. The maximum number of the animals that can stay on Kamusehk at the same time is slightly more than 50 individuals (depending on animal size and water level, Table 3).

The maximum duration of molting on floating ice (in the northern part - 40 days) and the small number of animals on the coastal rookery were recorded in 2011, especially starting from August (Table 3). By the number of haul-outs, $12 \%$ of moulting individuals were recorded in June, $22 \%$ - in July, $8 \%$ - in August, $15 \%$ - in September, and 24\% - in October (Table 3). The relatively small number of moulting animals in the haul-outs is explained by the fact that the seals that live in the northern part (the first visitors of the Ushkan Islands rookeries) mostly moulted on floating ice and did not go ashore en masse. However, from August 22 to September 9, there were no seals on the shore at all. Later in September, the seals that arrived mostly finished molting. Most likely, the southern animals did not have enough time to moult on the ice (9 days) en masse. But they reached the islands later (in October), possibly on their way to Chivirkuy Bay, where thousands animals migrate in autumn when the water begins to freeze. It is necessary to consider that in the southern part of Baikal, there are few active rookeries (Petrov \& Kupchinsky, 2021), and the anthropogenic influence on animals is significant (including roo- keries); therefore, the moulting of "southern" seals may be significantly prolonged.

\section{Table 1}

Ice period (I), beginning of ice breaking (II), and the end of floating ice clearing (III) in South and North Baikal

\begin{tabular}{ccccccc}
\hline \multirow{2}{*}{ Year } & \multicolumn{3}{c}{ Southern Part } & \multicolumn{3}{c}{ Northern Part } \\
\cline { 2 - 7 } & I & II & III & I & II & III \\
\hline 2011 & 14.01 & 30.04 & 09.05 & $\approx 01.01$ & $\approx 13.05$ & 23.05 \\
2012 & 26.01 & 20.04 & 07.05 & 16.01 & 26.04 & 20.05 \\
2013 & 08.01 & 30.04 & 16.05 & 30.12 .2012 & 18.05 & $06.06^{6}$ \\
2014 & 27.01 & 13.04 & 04.05 & 17.01 & 04.05 & 19.05 \\
2015 & $31.01^{1}$ & $04.04^{2}$ & 01.05 & $\approx 1.01$ & 07.05 & 20.05 \\
2016 & 18.01 & $11.04^{3}$ & $06.05^{4}$ & 08.01 & 05.05 & 23.05 \\
2017 & 20.01 & 17.04 & $04.05^{5}$ & 08.01 & 05.05 & $27.05^{7}$ \\
\hline
\end{tabular}

Note: ${ }^{1}$ - the ice in the southern part is formed, but transverse sections of open water were observed throughout February and almost until March; ${ }^{2}$ - open water at Selenga River area, 10.04 - the wide water opening, 16.04 - along the west coast, the open water was $>100 \mathrm{~km} ;{ }^{3}$ - first cracks across the lake appeared; 21.04 - water opened along the west coast up to the Ushkan Islands; ${ }^{4}-25.04$ - the destruction of the ice sheet began simultaneously throughout Southern and Central Baikal; ${ }^{5}$ - ice destruction to the delta of Selenga River, ${ }^{6}$ - near Dagara Bay, the ice kept up to $1-2.06 ;{ }^{7}$ the water opened on Cape Khoboy (Olkhon Island), except for Baykalsk Town region.

\section{Table 2}

Duration of ice period and ice sheet destruction from the beginning to the final clearing (II) in South and North Baikal (per days)

\begin{tabular}{crccc}
\hline \multirow{2}{*}{ Year } & \multicolumn{2}{c}{ Southern Part of the Lake } & \multicolumn{2}{c}{ Northern Part of the Lake } \\
\cline { 2 - 5 } & \multicolumn{1}{c}{$\mathrm{I}^{*}$} & \multicolumn{1}{c}{$\mathrm{II}^{*}$} & \multicolumn{1}{c}{ I } & II \\
\hline 2011 & $105(80)$ & $9(22)$ & 132 & 40 \\
2012 & $83(84)$ & $17(50)$ & 99 & 34 \\
2013 & $111(84)$ & $16(89)$ & 132 & 18 \\
2014 & $75(71)$ & $21(140)$ & 106 & 15 \\
2015 & $63(50)$ & $26(200)$ & 126 & 13 \\
2016 & $82(71)$ & $25(139)$ & 116 & 18 \\
2017 & $86(74)$ & $17(77)$ & 116 & 22 \\
\hline
\end{tabular}

Note: * - in brackets - the \% ratio of I south to I north, and II south to II north.

According to the haul-out on Kamushek, in 2012, there were more seals than in 2011 due to the high-water level. However, the authors noted that there were also more moulting animals (Table 3). This year was distinguished by the shortest ice period in the northern part of the lake (25\% shorter than the previous one), but a sufficiently long time of "life" of floating ice, sufficient for animals to moult typically. In the northern part, it was 34 days (Table 2). However, about $60 \%$ of the animals on the shores continued moulting. In 2014, the floating ice disappeared very quickly, especially in the northern part (Table 1,2) - in just two weeks. However, in the southern part of the lake, the floating ice stayed for three weeks, which should have been enough to complete the molting successfully.

\section{Discussion}

According to Ivanov (1938), after the disappearance of floating ice, the seals begin migrating south. The animals that did not have time to moult go to the nearest shore rookery. This can explain the high percentage of molting animals at the beginning of the season (68\% in June). In the other months, the moulting animals formed one-third of the seal number on the haul-outs (Table 3). Completely different situations were seen when the number of moulting animals was estimated in other rookery sections (not on Kamushek). While in May, there were $40.0 \pm 3.9 \%$ $(n=25)$ of these animals, in June and until September, there were very few of them. The reason for such a difference is still unclear.

The difference between these data and the Kamushek data may be due to the low water level, in which mostly large and strong individuals selected the Kamushek region. Their moulting may not be quite the same as of the young (small) individuals. In 2015, there were only August observations. The 395 seals were in close-up shot, and no more than $6 \%$ of them were moulting. It is possible that the animals had managed to moult in the southern and middle parts of the lake (south of the Ushkan Islands), where the floating ice remained for 26 days. 
Table 1

The average maximum number of seals per day on Kamushek

\begin{tabular}{|c|c|c|c|c|c|}
\hline Year and moulting & June & July & August & September & October \\
\hline 2011 & - & $31 \pm 2.9(21) 44$ & $13 \pm 3.5(25) 44$ & $22 \pm 4.0(22) 45$ & $13 \pm 4.5(18) 46$ \\
\hline$\%$ moulting ${ }^{1}$ water level & $12.4(5) 456.32(22.06)$ & $22 \pm 3.7$ (9) 456.51 (15.07) & $8 \pm 2.1(9) 456.71(19.08)$ & $15 \pm 1.63(20) 456.78(14.09)$ & $24 \pm 3.5(18) 456.73(20.10)$ \\
\hline 2012 & $33 \pm 2.5(26) 48$ & $42 \pm 1.8(9) 31-47$ & $34 \pm 5.2(5) 20-62$ & $33 \pm 2.9(5) 24-42$ & \\
\hline$\%$ moulting water level & $64 \pm 2.4(23) 456.49$ & $57 \pm 4.9(8) 456.71$ & $61(5) 456.86$ & $36(6) 456.91$ & - \\
\hline 2014 & $40 \pm 1.7(12) 48$ & $40 \pm 1.4(16) 47$ & $39 \pm 2.0(24) 50$ & $23 \pm 4.9(19) 48$ & $11 \pm 3.5(20) 42$ \\
\hline$\%$ moulting & $68 \pm 1.7(11)$ & $37 \pm 5.1(14)$ & $27 \pm 3.0(18)$ & $39 \pm 5.6(8)$ & $32 \pm 6.0(5)$ \\
\hline$\%$ moulting ${ }^{1}$ water level & $5 \pm 0.5(47) 456.35$ & $6 \pm 0.7(26) 456.50$ & $6 \pm 0.5(70) 456.57$ & $7 \pm 0.9(15) 456.53$ & -456.43 \\
\hline$\overline{2016^{2}}$ & 0 & 0 & & & \\
\hline$\%$ moulting $^{1}$ & 32 & 28 & & & \\
\hline$n$ (seals) & 83 & 192 & - & - & - \\
\hline water level & 456.01 & 456.15 & & & \\
\hline 2017 & 0 & 5 & 13 & 3 & 7 \\
\hline$\%$ moulting $^{1}$ & $36 \pm 2.4(101)$ & $19 \pm 7.6(122)$ & $15 \pm 1.8(52)$ & - & - \\
\hline water level & 456.13 & 456.22 & 456.25 & 456.26 & 456.24 \\
\hline
\end{tabular}

Note: ${ }^{1}$ - screenshot or photography identification from different parts of the rookery (not in Kamushek); ${ }^{2}$ - no sharpness, difficult to determine the hair cover; the number of moulting individuals (\%), and the water level (wl., m above sea level) at the end of the month, unless a different date is specified (pc., $\mathrm{x} \pm \mathrm{SE}, \mathrm{n}-\mathrm{observation}$ days).

In 2016, when the water level was low, no seals were seen on Kamushek in June or July. They could not cross the rocks to reach this rookery ground. On the other sites, about one-third of the animals continued to moult (Table 3). In the following 2017 year, the situation was identical: the water level was low, and the number of individuals on Kamushek was minimal in all months (Table 3). The number of moulting animals on other rookery grounds was low at record levels (except in 2011): most of the animals managed to moult on ice, although the length of the "life" period of the floating ice was close to the average (Table 1,2).

Years 2016 and 2017 indicated that moulting is not always associated with the duration of ice "life". The rate of moulting of seals likely depends not only on the longevity of the substrate (ice) but also on something else that one can only assume since the full-fledged monitoring of the seal population has not yet been conducted for an suficiently long time and now it is long overdue. However, for example, moulting rate depends on the nutritional status of animals (Pastukhov, 1993) and is also related to the degree of infestation by parasites. In other words, this mean that moulting rate also depends on the degree of infestation (Ivanov, 1938). For pups, first moulting depends on weather conditions (snow amount) and nutritional status (Ivanov, 1982).

After monitoring the behaviour of the animals, the authors concluded that the main reason for the animals to come to the land is not molting, as there are many moulted animals at the rookeries. They come in large numbers due to the physiological need for solar radiation. Adequate lighting is known as a prerequisite for the normal functioning of mammals. During months of living under solid ice and snow cover (in the dark), seals are likely to develop a lack of natural ultraviolet radiation. That is why, early as the first days of spring, the animals tend to get out (starting at the end of March) and spend as much time as possible in the air (on ice). With the beginning of ice breakage (Fig. 1), virtually all Baikal seals spend most of the day on floating ice (in warm weather, not simultaneously, and in different places). They form numerous moulting haul-outs, dive, hunt, and their activities shift to nighttime (Stewart et al., 1997). In mammals, which were studied mainly on agricultural and fur (cage) animals (Shmanenkova, 1978), solar radiation largely affected the skin.

Infrared radiation, penetrating and heating the animals' skin (hyperemia), enhances metabolic processes and activates phagocytosis. Visible light rays also stimulate the whole animal organism, including the internal secretion glands. By improving the supply of oxygen to tissues (through respiratory and circulatory organs), ultraviolet rays significantly impact physiological processes such as seasonal moulting and embryogenesis. It penetrates the skin, causing the formation of substances, including vitamin D (its deficiency is caused by light starvation in winter). Vitamin D normalizes calcium-phosphorous metabolism and is particularly important for the growing organism (seal pups spend much time on ice).

The intensity of UV radiation changes over the day and sharply increases around $4 \mathrm{pm}$. Its peak is in July. However, the authors did not detect the corresponding daily dynamics of the number of seals on the rookery, as well as increase in the haul-out size in July compared to other months (Petrov et al., 2021). The beginning of seasonal moulting is stimu- lated by the change in the length and intensity of the daylight, which affects the pituitary gland through visual perception. Blood vessels of the peripheral tissues of seals ( primarily skin) expand in summer on air (outside water) (Baranov et al., 1992). It leads to increased hair growth, sealing of the epidermis, which increases the skin resistance, tissue growth and regeneration, healing of wounds, and ulcers (bactericidal effect).

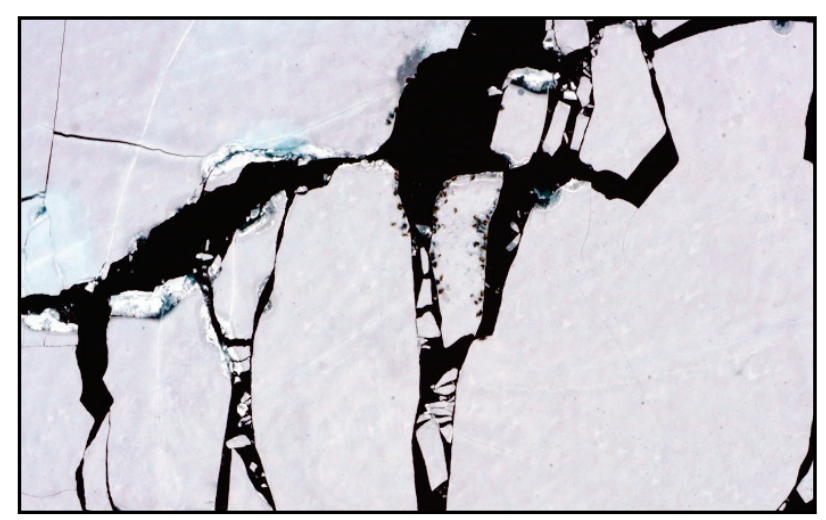

Fig. 1. The first seal haul-outs on the edge of the ice are formed on spring water openings, where seals rest: the populations of seals become large and the animals start moulting only on the floating ice (aerial photograph from 300 m altitude, May 13, 2019, Svyatoy Nos Peninsula region); Bizikov et al. (2019)

That is why at the rookeries, many animals are suffering from various dermatological diseases (pathologies). That is why the rookery grounds may be called the "health resort", where the number of "patients," as shown on video observations, changes from year to year. During the monitoring of the animals on the Kamushek, the authors found that almost $50 \%$ of the animals had injuries, such as ulcers, scars, and diseases, often affecting large areas of the body in each haul-out. In 2012, the authors recorded 108 cases of injuries of the skin-fat cover in 33 days of observation; in 2014 - 256 cases in 58 days. The scapula and sacrum were observed to be the most vulnerable parts of the seals' body, where the authors detected $67 \%$ of all "dermatitis." Besides, there were fresh, often hemorrhaging wounds (6 and 12 animals, respectively). There were also animals with baldness of various body parts. In 2012, hair-free skin was observed in 47 individuals; in 2014 - in 120 individuals. In June of 2017, in the haul-outs with the average number of $13.0 \pm 0.59$ individuals (n, number of observations, 105) seals with various pathological signs on the body accounted for $44.5 \%(n=94)$. The origin of the above-mentioned skin-hair pathologies needs to be studied. In addition, fresh, often bleeding wounds were seen (in 6 and 12 seals in 2012 and 2014, respectively). The nature of some wounds clearly indicates that seals inflict tangible wounds upon each other. However, no such cases were recorded on the video materials; but often, one could observe seals biting or trying to bite each other (Fig. 2). 


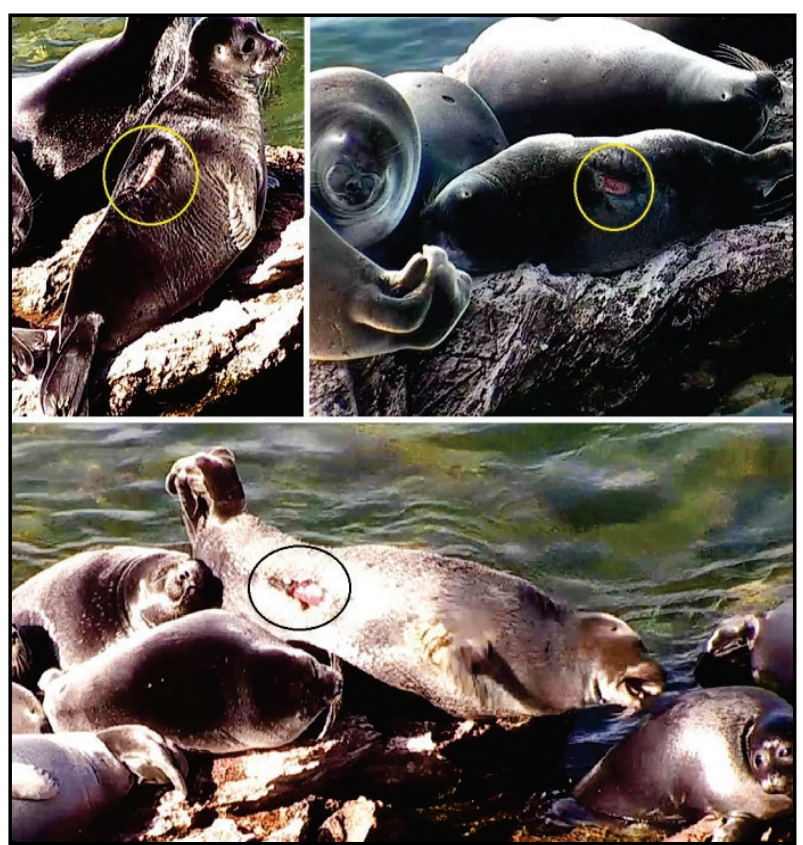

Fig. 2. These fresh lacerations are most likely the result of the animals' interactions with each other: in the lower photo, the injured seal tries to bite its neighbour (12 photos, July 20, 2017)

Thus, shore rookeries are necessary for some parts of the seal population to maintain (recover) health and heal wounds. Climatic changes cause an increase in the relative number of individuals that were unable to complete the moulting on ice. In this sense, the summer-autumn shore rookeries are not an extension of the spring ice moulting haul-outs (Ivanov, 1938). They perform their "healing" function, and are not attributed to the seals that need to complete the moulting. Maybe, seals at rookeries do not moult in rookeries in the typical way (by rubbing against the surfaces), and lie quietly under rays of the sun (Petrov et al., 2021).

However, if the moulting delay and its prolongation can be considered pathological processes, then the function of shore rookeries is certainly healing. However, the excessive prolongation of the time "under the sun" (in this case - outside the water, on the ice, or the shore) affects embryogenesis. In the conditions of "long days - short nights," sheep and horses suffer from premature pregnancy termination, and impairment of the deposition of fats is considered the primary cause leading to such an effect (Cherednichenko, 1979; Folk, 1969).

Probably, this phenomenon was also observed in 1981 when, to complete the moulting after the unusual early ice disappearance (for that period), seals in large numbers traveled to the shore (Pastukhov, 1993), spending perhaps too much time on it. The changes took place according to this pattern:

- moulting period prolongation;

- change of behaviour and time in favour of the "shore" period;

- shortening of the fattening period;

- change of seasonal fat accumulation;

- impairment of embryogenesis (as a result, the barrenness of females quadrupled, up to $63 \%$ ).

It is noteworthy that extreme ice conditions since the late 1990s have become common in Baikal. Today, the ice clearing of the southern part occurs on average 15 days earlier than in the 1960-1980s. This is not surprising, as $\mathrm{T}_{\mathrm{w}}$ is rising annually in May-September. In August of the early 2000s, even on the central sections of the lake, the water warmed up to $18-20^{\circ} \mathrm{C}$. From 1940 to 2005 in southern Baikal, the period with $\mathrm{T}_{\mathrm{w}}>$ $10^{\circ} \mathrm{C}$ increased by 11 days, the homoiothermic in spring began eight days earlier, and in autumn - 11 days later (Shimaraev et al., 2002). However, we should emphasize that there were no drastic impairments of the embryogenesis processes during these years. In any case, the index of the females' infertility did not exceed the average values (Petrov, 2009). In the 1990s, most likely, in accordance with the relative alignment of the surface $T_{w}$ during the open water period, the distribution of seals in the water area during the feeding period changed (Petrov, 1993).
The widespread distribution of the Baikal seal in the summer in the entire water area of the lake, including the coastal area, persists even today. Furthermore, according to our data, the need for coastal rookeries has increased. On July $28-31,2020$, the ice disappeared almost two weeks earlier), the authors surveyed about $200 \mathrm{~km}$ of the coast (Listvyanka eastern coast of Olkhon Island - islands of the Maloe More) from the boat.

They found 20 additional sealslocations with $\approx 1000-1100$ individuals (according to visual observations) - animals swimming close to rookeries). The discovered locations are not on the list of known shore rookeries (Ivanov, 1938; Petrov \& Kupchinsky, 2021). Thus, seals need to go ashore. Since there are not enough suitable sites to form haul-outs, a change in the "membership" (rotation) must occur at the rookeries. The authors believe that there are many such animals in the population - they travel ashore throughout summer and autumn until the first ice formation in the bays and in shallow waters (where the seals go a little later).

The authors discuss the level of danger of further warming for the Baikal seal population. Paleoclimatic reconstructions show that even assuming that the seals' ancestors entered Baikal during the last glacial era (rather than earlier), then from the end of the Pleistocene they have safely survived many serious cataclysms, primarily climatic ones. After glaciation, climate mitigation began 18-17 thousand years ago. For the period $16-11$ thousand years ago, scientists have identified cycles $\approx 1250$ years) in the climate dynamics of Siberia. Their maximum values of $T_{a}$ and $T_{w}$ were close to the current values. However, at the lower points of the cycles, $\mathrm{T}_{\mathrm{a}}$ dropped by $6-7^{\circ} \mathrm{C}$ and $\mathrm{T}_{\mathrm{w}}-$ by $4-5^{\circ} \mathrm{C}$. As a result, Baikal was frozen for 7.5-8.0 months of the year, and the ice-free period (feeding time for the seals) reduced to 120-140 days (Shimaraev \& Mizandrontsev, 2004). About 11 thousand years ago, the Baikal glaciers began to melt intensively, and abiotic conditions drastically changed - it became warm. Summer $\mathrm{T}_{\mathrm{w}}$ in Baikal (10.8-8.8 thousand years ago) increased to $10^{\circ} \mathrm{C}$, ground vegetation developed intensively, increasing nutrient input, the fattening period of the seal increased to ten months, and ice - decreased to two months. From almost zero "glacial" level, the annual biomass of phytoplankton grew up to $100-1000$ times, starting from 3711 thousand years ago (Khursevich et al., 2001). About eight thousand years ago, against the background of mountain glaciers melting and as the terrigenous drift began to slow down, becoming biogenic, the water became more transparent. The "deep restructuring of the ecosystem of Baikal" started (Bezrukova et al., 1991). It included the rapid development of current species of diatoms. Starting from six thousand years ago, a slow cooling began. The minimum values of $T_{a}$ and $T_{w}$ did not drop below the current values, and the maximum values were 1-3 degrees higher, preserving a prolonged ice-free period (9-10 months). Over the next 3,000 years, the climate fluctuated, but the lake characteristics gradually approximated the current values (Shimaraev \& Mizandrontsev, 2004). For other climate reconstructions, the dynamics of the processes are similar, but the timeline varies slightly.

Based on the current ecology and the biology of seals, both extremes glaciation and warming - are undesirable for these mammals. According to Pastukhov (1993), an ice cover thickness of 1.5-2.0 times more than the current one will not be dangerous for the Baikal seal. Moreover, if Baikal were to freeze for the whole year, the seal could safely survive a year or two even under such conditions (Pastukhov, 1993). The authors find the latter statement doubtful, although, according to the reconstructions, after the determination of seasonality in the region, Baikal has never frozen for an entire year (even in the coldest periods of glaciers). On the other hand, the lake has never been left uncovered by ice, even in the warmest days of the Holocene the ice sheet was preserved for a short time. Still, the Baikal seal will survive. We can only assume how this affected the reproduction and abundance of the population. The species survived, and the seals' population recovered.

If the warming continues, the winter conditions of Baikal by 2050 will be very unfavourable, if not critical, for the seals. The ice of southern Baikal will be thin (30-40 cm, now it is 60-70), the period of ice will be shortened by half (two months), and even winters with unstable ice are possible (Shimaraev et al., 2014). According to another model, by 2050 , the maximum ice thickness $\left(\mathrm{H}_{\max }\right)$ will be reduced to $50 \mathrm{~cm}$ and by $2100-$ to approximately $31 \mathrm{~cm}$ (Kuimova \& Sherstyankin, 2008). The winter ice duration, which currently is $120-135$ days, by 2100 , will be reduced: in 
the southern part of the lake - to 56-60 days, in the northern - to 75 days (Shimaraev et al., 2014). Over recent years, the average duration of the ice period in southern Baikal has been $86 \pm 2$ days ( $\mathrm{n}=7$ years), and in the north $-118 \pm 4.8$ days (Table 2 ).

The minimum time for milk-feeding of seal pups is 45 days, but depending on the time and geographical location, the period of birth of pups (stretched in time for at least 1.5 months) can be much longer - up to 75 days. It is clear that if the predictions become true, the existence of the seal population in its present form would not be possible. If the southern part of the lake does not have a seasonal ice sheet, the distribution of the entire population will inevitably change. It will change the nutritional conditions. Most likely, the reproductive part of the population will stay in the areas where ice formation will continue. As a seasonal phenomenon, the ice on Baikal should be preserved (Kuimova \& Shersteinkin, 2008). However, the situation would become critical if habitat became fragmented, having only parts of Baikal frozen (e.g., bays of the Small Sea). A short winter will negatively impact the survival of pups (Fig. 3), causing a rapid decline of the population.

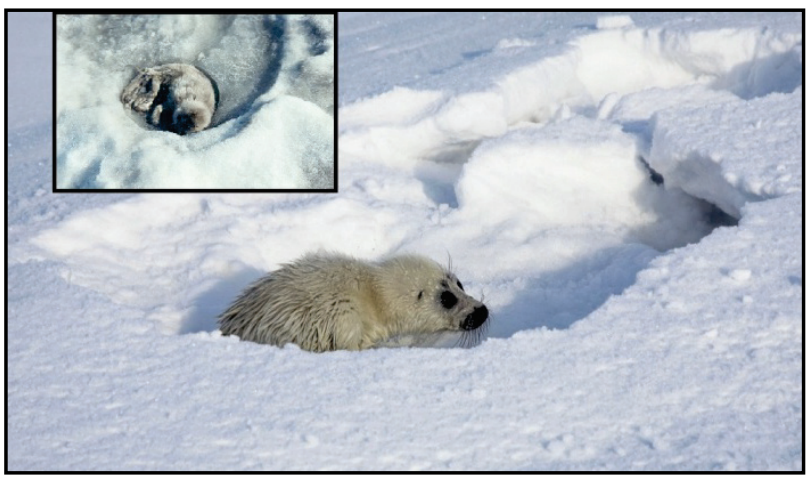

Fig. 3. Young white pup of a Baikal seal is defenseless and usually dies if the birth lair disappears too soon

The hypothetical total absence of ice on Baikal would lead to rapid decrease and extinction of the seals' population since the disruption of the moulting process would immediately affect the reproductive potential, and pups born on land would be exterminated by aerial and terrestrial predators (Pastukhov, 1993). Petrov (1997) assumed the experience of the extreme 1981. But, as noted above, the population responded surprisingly quickly to similar "extreme" years in terms of embryogenesis development. For many years, the ice on Baikal has been disappearing earlier, but seals continue to moult on floating ice, and nothing extraordinary is happening. The most likely negative impact in the near future will be the physical death of some of the pups. Based on ideas on the impact of global warming on the Arctic and sub-Arctic mammals (Laidre et al., 2008), the vulnerability of the Baikal seal is increasing due to the relatively small total population and limited water area. The authors doubt the first statement because it does not consider the range (the number of the Baikal seals per square $\mathrm{km}$ is not small). The second statement is fair: it involves almost simultaneous onset of adverse conditions throughout the entire area, and therefore the inability to leave unfavourable areas. However, the lifestyle of the Caspian and ringed seals (Saimaa, Ladoga, and Baltic) is an example of how pagophilic seals can adapt to problems with ice (and snow). As the last variant, their "experience" allows us to assume the possibility of a transition of the Baikal seal to terrestrial procreation. In this case, in a mild climate, the threat of dying from frost will disappear, and the pups on Baikal are unlikely to be completely destroyed due to the absence of serious predators. However, the issue is arguable - if brown bears cease to hibernate during the winter, they may adopt the habits of the polar bear.

\section{Conclusions}

The Baikal seal population has been living for many years under climate warming, and people hope that it can adapt to change since the climate change is not catastrophic.

As early as the 1990s, the distribution of animals over the fattening period (Petrov, 1997) changed due to the relative alignment of surface water temperature during the open water period. The extensive use of the entire lake area (including the shoreline) during the summer period continues. Compared to 1960-1980, there is no doubt that the fattening period has extended; there has been a shift towards time spent on land.

On the other hand, the time the seals spend on and under the ice has reduced. The animals spend the winter in softer conditions that allow them to reduce energy consumption, decrease the amplitude of seasonal fluctuations of body mass and nutritional state. These changes are associated with the recent phenomenon: many animals came to shore rookeries. They are so well-nourished (Petrov \& Kupchinsky, 2021) that the question arises where and how are they spending the winter. Therefore, in terms of the Baikal seal physiology, the climate warming probably should not be considered a threat to the seal population.

The visible part of the population is experiencing a shift of the annual time budget towards life on land. Coastal haul-outs are becoming more numerous, and seals are developing new places for the shore rookeries. If the authors' conclusion on the main purpose of the shore rookeries is correct (the rookeries have a healing function), then the increase in the role of the shore in the life of the seal is mainly due to the increase in the number of animals with unfinished moulting, that is, with an increase in the proportion of ill animals in the population determined by the changing ice regime (but not to the deterioration of animal health in the population). However, the seasonal reduction of the total area (decrease of ice cover) and deterioration of the ice quality is a serious change in the habitat for the seal. The early destruction of the ice cover and the birth lairs should not only increase the mortality of pups but also shorten the lactation time, worsening the physical indexes of pups, primarily the amount of subcutaneous fat deposited (Egorova \& Petrov, 1998). In the 1990s, the definite feeding period (transition from milk to fish diet) for seals in the southern part of the lake occurred on May 5-10, in the northern part - on May 1520 (Egorova \& Petrov, 1998). Currently, it occurs two-three weeks earlier. Unfortunately, in the near future, lack of feeding may have negative consequences for the functioning of the entire seal population. The insufficient weight and body size of the pup will affect further growth and sexual maturation of the animal and its future offspring (Pastukhov, 1993). In this respect, warming can be seen as a real threat. The mentioned processes and changes have likely been occurring in recent years, but no relevant published information is available.

The history of Baikal seal population allows us to look optimistically at its future, in the view of the climate warming - the population may decline but certainly not disappear.

The research was carried out within the framework of the budgetary theme of the Baikal Museum, there is no conflict of interest.

\section{References}

Baranov, V. I., Elagin, O. K., Korokhov, V. P., Petrov, E. A., Chermnykh, N. A., \& Shoshenko, K. A. (1992). Organnoye krovoobrashcheniye baykal'skoy nerpy pri izmenenii temperatury i nyryanii [Organ blood circulation of the Baikal seal at temperature change and diving]. Bionika, 25, 98-108 (in Russian).

Bezrukova, E. V., Bogdanov, J. A., Williams, D. F., Granina, L. Z., Grachev, M. A., Ignatova, N. V., \& Yakushin, A. O. (1991). Glubokiye izmeneniya ekosistemy Severnogo Baykala $v$ golotsene [Deep changes of the Northern Baikal ecosystem in the Holocene]. Reports of the Academy of Sciences, 321(5), 1032-1037 (in Russian).

Bizikov, V. A., Boltnev, E. A., Petrov, E. A., Peterfeld, V. A., \& Chernook, V. I. (2019). Eksperimental'naya avias'yomka baykal'skoy nerpy s ispol'zovaniyem BPLA bol'shoy dal'nosti [Experimental aerial photography of the Baikal seal using long-range drones]. VNIRO Journal, 175, 226-228 (in Russian).

Cherednichenko, L. K. (1979). Prirodnyye faktory sredy i ikh vliyaniye na organizmy [Natural factors of the environment and their influence on organisms]. In: Slonim, A. D. (Ed.). Ecological physiology of animals, part 1. General ecological physiology and physiology of adaptation. Nauka, Leningrad. Pp. 36-78 (in Russian).

Egorova, L. I., \& Petrov, E. A. (1998). Nekotoryye ekologo-fiziologicheskiye aspekty pitaniya i rosta shchenkov baykal'skoy nerpy (Pusa sibirica) [Some environmental-physiological aspects of feeding and growth of Baikal Seals (Pusa sibirica)]. Journal of Evolutionary Biochemistry and Physiology, 34(5), 591597 (in Russian).

Fialkov, V. A., Badardinov, A. A., Egorov, V. V., \& Melnikov, Y. I. (2014). Baykal $\mathrm{v}$ rezhime real'nogo vremeni: Tekhnicheskiye resheniya i nauchno-prosveti- 
tel'skiye zadachi [Baikal in real time: Technical solutions and scientific and educational tasks]. Development of Life, 3, 476-485 (in Russian).

Folk, G. E., Jr. (1969). Introduction to environmental physiology. Lea \& Febiger, Philadelphia.

Ivanov, M. K. (1982). Kozhno-volosyanoy pokrov baykal'skoy nerpy [The skin and hair cover of the Baikal seals]. In: Pastukhov, V. D. (Ed.). Morfofiziologicheskiye i ekologicheskiye issledovaniya baykal'skoy nerpy [Morphophysiological and environmental studies of Baikal seals]. Nauka, Novosibirsk. Pp. 20-39 (in Russian).

Ivanov, T. M. (1938). Baykal'skaya nerpa, yeye biologiya i promysel [Baikal seal, its biology, and hunting]. News of the Bio-Geographical Research Institute at the East Siberian State University, 8, 5-119 (in Russian).

Khursevich, G. K., Karabanov, E. B., Prokopenko, A. A., Williams, D. F., Kuzmin, M. I., Fedenya, S. A., \& Kerber, E. V. (2001). Detal'naya diatomovaya biostratigrafiya osadkov ozera Baykal v epokhu bryunes i klimaticheskiye faktory vidoobrazovaniya [Detailed diatoms biostratigraphy of the precipitation of Lake Baikal during the Brunes era and climatic factors of speciation]. Geology and Geophysics, 42, 108-129 (in Russian).

Kuimova, L. N., \& Shersteinkin, P. P. (2008). Analiz izmenchivosti kharakteristik ledovogo rezhima ozera Baykal i Arktiki po materialam nablyudeniy s 1950 goda [Analysis of the variability of the ice regime of Lake Baikal and the Arctic based on observations since 1950]. Materials of Glaciological Studies, 105, 140-144 (in Russian).

Kuimova, L. N., \& Shersteinkin, P. P. (2008). Analiz izmenchivosti kharakteristik ledovogo rezhima ozera Baykal i Arktiki po materialam nablyudeniy s 1950 goda [Analysis of the variability of the ice regime of Lake Baikal and the Arctic based on observations since 1950]. Materials of Glaciological Studies, 105, 140-144 (in Russian).

Laidre, K. L., Stirling, I., Lowry, L. F., Wiig, Ø., Heide-Jørgensen, M. P., \& Ferguson, S. H. (2008). Quantifying the sensitivity of arctic marine mammals to climate-induced habitat change. Ecological Applications, 18(2), 97-125.

Numachi, K., Sasaki, H., Petrov, E., \& Grachev, A. M. (1994). Low genetic variability of mitochondrial DNA genome in Baikal seal, Phoca (Pusa) sibirica [Nizkaya geneticheskaya izmenchivost' genoma mitokhondrial'noy DNK baykal'skoy nerpy Phoca (Pusa) sibirica]. Report on Studies on the Animal Community, Phylogeny and Environments in Lake Baikal, 120, 17-24 (in Russian).

Pastukhov, V. D. (1993). Nerpa Baykala. Biologicheskiye osnovy ratsional'nogo ispol'zovaniya i okhrany resursov [Baikal Nerpa. Biological bases of rational use and protection of resources]. Nauka, Novosibirsk (in Russian).

Petrov, E. A. (1997). Raspredeleniye baykal'skoy nerpy Pusa sibirica [Distribution of the Baikal seal Pusa sibirica]. Zoological Journal, 76(10), 1202-1209 (in Russian).

Petrov, E. A. (2003). Baykal'skiy tyulen': Ekologo-evolyutsionnyye aspekty [Baikal seals: Environmental-evolutionary aspects]. Buryat State University, Ulan-Ude (in Russian).
Petrov, E. A. (2009). Baikalskaya nerpa [Baikal seal]. Ekos, Ulan-Ude (in Russian).

Petrov, E. A., \& Kupchinsky, A. B. (2021). Beregovyye lezhbishcha baykal'skoy nerpy Pusa sibirica Gm. (po materialam video nablyudeniy): 1. Nekotoryye kolichestvennyye otsenki funktsionirovaniya lezhbishcha na o-ve Tonkiy (arkhipelag Ushkani o-va, oz. Baykal) [The shore rookeries the Baikal seal Pusa sibirica $\mathrm{Gm}$. (based on video observations): Some quantitative estimates of the functioning of the rookery at Tonky Island of Ushkany Islands, Lake Baikal (Ushanja Island, Oz. Baikal)]. ISU Publishing, Irkustsk (in Russian).

Petrov, E. A., Kupchinsky, A. B., Fioakov, V. A., \& Badardinov, A. A. (2021). Znacheniye beregovykh lezhbishch v zhizni baykal'skoy nerpy (Pusa sibirica Gmelin 1788, Pinnipedia) [The importance of shore rookeries in the life of Baikal Seals (Pusa sibirica Gmelin 1788, Pinnipedia]. Zoological Journal, 100(6), 671-685 (in Russian).

Sasaki, H., Numachi, K., \& Grachev, M. A. (2003). The origin and genetic relationships of the Baikal seal, Phoca sibirica, by restriction analysis of mitochondrial DNA. Zoological Science, 20, 1417-1422.

Shimaraev, M. N., \& Mizandrontsev, I. B. (2004). Reconstruction of abiotic conditions in Baikal in the late Pleistocene and Holocene. Geology and Geophysics, 45(5), 557-564.

Shimaraev, M. N., Kuimova, L. N., \& Sinyukovich, V. N. (2014). Tendentsii izmeneniya abioticheskikh usloviy Baykala v sovremennyy period. Razvitiye zhizni $\mathrm{v}$ protsesse abioticheskikh izmeneniy na Zemle [Trends in changes of abiotic conditions in Baikal in the modern period. The development of life in the process of abiotic change on Earth]. Proceedings of the III all-Russian Scientific and Practical Conference. Listvyanka, Irkutsk. Pp. 230-237 (in Russian).

Shimaraev, M. N., Kuimova, L. N., \& Tsekhanovsky, V. V. (1991). Mnogoletniye izmeneniya ledovo-termicheskogo rezhima na Baykale [Perennial changes of the ice-thermal regime on Baikal]. In: Izrael, Y. A., \& Anokhin, Y. A. (Eds.). Monitoring i otsenka sostoyaniya Baykala i Pribaykal'ya [Monitoring and assessment of the state of Lake Baikal and Baikal region]. Hydrometeoizdat, Leningrad. Pp. 64-70 (in Russian).

Shimaraev, M. N., Kuimova, L. N., Sinyukovich, V. N., \& Tsekhanovsky, V. V. (2002). O razvitii global'nogo izmeneniya klimata na Baykale v XX veke [About the development of global climate change in Baikal in the 20th century]. Reports of the RAS, 383(3), 397-400 (in Russian).

Shimaraev, M. N., Troitskaya, E. S., \& Gnatovsky, R. Y. (2009). Izmeneniye temperatury vody na Baykale $\mathrm{VXX}$ veke [Water temperature changes in Baikal in the 20th century]. Geography and Natural Resources, 3, 68-76 (in Russian).

Shmanenkova, N. A. (Ed.). (1978). Fiziologiya sel'skokhozyaystvennykh zhivotnykh [Physiology of agricultural animals]. Nauka, Leningrad, USSR (in Russian).

Stewart, B., Petrov, E., Baranov, E., Timonin, A., \& Ivanov, M. (1997). Seasonal movements and dive patterns of juvenile Baikal seals, Phoca sibirica. Marine Mammal Science, 12(4), 528-542. 